\title{
Cocoon morphology of the cockroach-hunting apoid wasp Ampulex compressa (FABRICIUS) (Hymenoptera, Ampulicidae)
}

\author{
With 7 figures
}

Sandor Christiano Buys ${ }^{1}$

${ }^{1}$ Laboratório de Biodiversidade Entomológica, Instituto Oswaldo Cruz, Fundação Oswaldo Cruz, Avenida Brasil 4.365, Pavilhão Mourisco, sala 2014, Manguinhos, 21.045-900, Rio de Janeiro, RJ, Brazil. - sandor.buys@gmail.com Published on 2015-12-21

\section{Summary}

The cocoon morphology of the cockroach-hunting apoid wasp Ampulex compressa (FABRICIUs, 1781) (Hymenoptera: Ampulicidae) is described, based on five cocoons examined under binocular microscope. This is the first detailed description of cocoons of Ampulicidae. The examined material was obtained from a stock of wasps maintained in laboratorial conditions, using specimens of Periplaneta americana (Linnaeus, 1758) (Blattaria: Blattidae) as host. The cocoon is constructed within the exoskeleton of the host and has three capsules. The external and middle capsules are formed by structurally distinct types of silken threads, whereas the internal capsule is formed by a brittle substance, without distinguishable silken threads. The cocoons of A. compressa are morphologically distinct from those of the related families Sphecidae and Crabronidae and, perhaps, its complex and reinforced structure represents a kind of mechanic barrier that function in association with the antimicrobial oral secretions of the larvae as a protection against antagonistic microbes.

\section{Key words}

Immature stage, larvae, life history, taxonomy, biology, Sphecidae, Crabronidae

\section{Zusammenfassung}

Die hier beschriebene Morphologie des Kokons der Schaben jagenden apoiden Wespe Ampulex compressa (FABRICIUs, 1781) (Hymenoptera: Ampulicidae) basiert auf fünf unter einem binokularen Mikroskop untersuchten Kokons. Dies ist die erste detaillierte Beschreibung des Kokons von Ampuliciden. Das untersuchte Material wurde von unter Laborbedingungen gehaltenen Wespen gewonnen. Als Wirte wurden Tiere der Art Periplaneta americana (Linnaeus, 1758) (Blattaria: Blattidae) genutzt. Die Larven bauen ihren Kokon innerhalb des Exoskeletts des Wirts. Er besteht aus drei Kapseln. Die äußere und mittlere Kapsel werden durch strukturell unterschiedliche Seidenfäden gebildet. Die innere Kapsel wird hingegen von einer spröden Substanz ohne unterscheidbare Seidenfäden gebildet. Kokons von A. compressa unterscheiden sich morphologisch von denen der Arten der verwandten Familien Sphecidae und Crabronidae. Vielleicht stellt diese komplexe und verfestigte Struktur eine Art von mechanischer Barriere dar, die in Verbindung mit dem antimikrobiellen Mundsekret der Larven als Schutz gegen antagonistische Mikroben fungiert. 


\section{Introduction}

The cocoon of holometabolic insects can be seen as an end-product of a complex larval behavior; hence descriptions of cocoon structure are auxiliary in studies on biology of immature insects. Moreover, the cocoon morphology is potentially useful in systematic and phylogenetic studies (e.g. Matthews \& Matthews 1968, Stuart \& Hunter 1998, Buys 2004). Larvae of apoid wasps (Ampulicidae, Crabronidae, Heterogynaidae and Sphecidae), as a rule, spend their life enclosed inside nests, therefore, direct detailed observation of their development a lot of times is hard or impossible. Thus, descriptions of the cocoon structure of these wasps are especially valuable in furnishing information on larval behavior, as well as selective pressure suffered inside their nest. Even so, the cocoon structure of apoid wasps is still very poorly studied.

Ampulicidae is a widespread distributed family of cockroach-hunting solitary apoid wasps (BOHART \& MENKE 1976), with 200 species (Pulawski 2015). Ampulex compressa (FABRICIUS, 1781) is originally distributed in Oriental Region and possibly also in Ethiopian Region, but it has been established in other parts of the world and recently reaches the South America (Menke \& Yustiz 1983). General aspects of the biology of this species were described by WiLliams (1942). The female wasps capture and paralyze a cockroach, commonly Periplaneta americana (Linnaeus, 1758) (Blattaria: Blattidae), and drag her body to a preexistent cavity, which is used as nest. The wasp lays its egg on a leg of the roach; each nest is stored with only one prey item. The morphology of the mature larva of A. compressa was described by BuYs (2007).

In the present paper a morphological description of the cocoon of $A$. compressa is presented. This is the first detailed description of cocoons of Ampulicidae.

\section{Material and methods}

Five cocoons of A. compressa were dissected and studied under a Zeiss Stemi SV 6 binocular microscope. Measurements were done using an ocular micrometer. The cocoons were obtained from a stock of $A$. compressa maintained in the Laboratory of Medical Entomology of the Institute of Biophysics - Universidade Federal do Rio de Janeiro (Rio de Janeiro, Brazil), using specimens of P. americana as host. Voucher specimens were deposited in the Entomological Collection of the Instituto Oswaldo Cruz (Rio de Janeiro, Brazil).

\section{Results}

The cocoon is constructed within the exoskeleton of the host, occupying its entire abdomen and the major part of the thorax (Figs 1-2). After the larval development, the exoskeleton of the host seems to be virtually free from soft tissues, which apparently are entirely feed by the larva. The shape of the cocoon is approximately fusiform in sagital view and cylindrical in transversal view. The wasp's cocoon has three capsules, as follows:

External capsule: A dense tangle of coarse golden silken threads (Figs 2-3), which firmly adheres the cocoon to the exoskeleton of the roach. Both of the apical extremities have cylindrical openings, with about $0.75 \mathrm{~mm}$ in diameter (Fig. 3). The silken threads reach about $0.02 \mathrm{~mm}$ in diameter in median portion of the cocoon and about $0.04 \mathrm{~mm}$ in the extremities near the apical openings, where some larger threads are reddish-brown in color (Fig. 3).

Middle capsule: A very thin and malleable silken tissue, white in color, which entirely coats the internal capsule. This tissue is firmly adhered to the external capsule, but free from the internal capsule. In contrast to the external capsule, the silken threads of the middle capsule are not visible under the binocular microscope, even under high magnification.

Internal capsule: A fusiform capsule of hard and brittle substance, with no distinguishable silken threads. The thickness of the wall of this capsule varied from 0.08 to $0.4 \mathrm{~mm}$. The outer face is brown and shinning; the inner face is covered with a thin and translucent amber pellicle that confers a dark brown and shinning appearance (Fig. 6); without this pellicle the inner face is light brown and lusterless (Fig. 7). The wall in transverse cutting has porous texture and the color is pale, almost white in the center, and gradually darker toward the extremities (Fig. 5). The apical openings are closed with a plug of silken threads (Fig. 4). White grains of uric acid were observed free or attached to the walls of the internal capsule (Fig. 4).

\section{Discussion}

The cocoon structure of A. compressa is surprisingly complex and peculiar. BuYs (2004) comparatively studied the cocoon structure of the Sphecidae and observed that the wasps of this family made cocoons with one or two silken capsules imbibed with oral secretions expelled by the larvae; in the subfamilies Sceliphrinae and Chloriontinae the cocoons have only one capsule, whereas in the subfamilies Sphecinae and Ammophilinae the cocoons have two or three distinguishable capsules. However, not similar to the hard internal capsule observed in A. compressa was observed in cocoons of Sphecidae. Notoriously, among Sphecidae, cocoons of several species of Sphecinae, Ammophilinae and of the Sceliphrinae genus Penepodium Menke also bear openings in one or both of the apical the extremities (e.g. Buys 2001, 2004), similarly to those observed in A. compressa. In the apoid family Crabronidae the structure of the cocoons apparently is more variable than those of Sphecidae (e.g. Matthews \& Matthews 1968), but is still less known. 
HERZnERA et al. (2013) observed that larval A. compressa sanitize their hosts with a mixture of antimicrobials present in its oral secretion, since they need effective defense mechanisms against putrefactive and pathogenic microbes that are especially abundant in Periplaneta americana. Perhaps the complex reinforced structure of the cocoon of $A$. compressa represents a kind of mechanic barrier that function associated with the antimicrobial oral secretions as a protection against antagonistic microbes.

\section{Acknowledgements}

I thank Rodrigo Méxas for some of the photographs used in this paper and Jane Costa, Márcio Félix, Cláudia Rodrigues and Daniela Cerri for facilitating the work in the Laboratório de Biodiversidade Entomológica.

\section{References}

Bohart, R. M. \& Menke, A. S. 1976: Sphecidae wasps of the world: a generic revision. -Pp. ix + 695. Berkeley: University of California Press.
Buys, S. C. 2001: Last instar larva of Penepodium dubium (Hymenoptera: Sphecidae). - Revista de Biología Tropical 49 (1): 329-332.

Buys S. C. 2004: Estudos comparados sobre morfologia de imaturos e comportamento de Sphecinae (Insecta: Hymenoptera: Sphecidae): Pp. 134. - Rio de Janeiro: Doctoral thesis, Museu Nacional-Universidade Federal do Rio de Janeiro.

Buys S. C. 2007: Morphological studies on the last instar larva of Ampulex compressa (FABRICIUs) from Brazil (Insecta, Hymenoptera, Ampulicidae). - Spixiana 30 (1): 33-37.

Herznera, G.; Schlechta, A.; Dollhofera, V.; Parzefalla, C.; Harrarb, K.; Kreuzerb, A.; Pilslb, L. \& Ruther, J. 2013: Larvae of the parasitoid wasp Ampulex compressa sanitize their host, the American cockroach, with a blend of antimicrobials. - Proceeding of the National Academy of Sciences of United States of America 110 (4): 1369-1374.

Matthews, R. W. \& Matthews, J. R. 1968: A note on Trypargilum arizonense in trap nests from Arizona, with a review of prey preferences and cocoon structure in the genus (Hymenoptera: Sphecidae). - Psyche 75: 285-293.

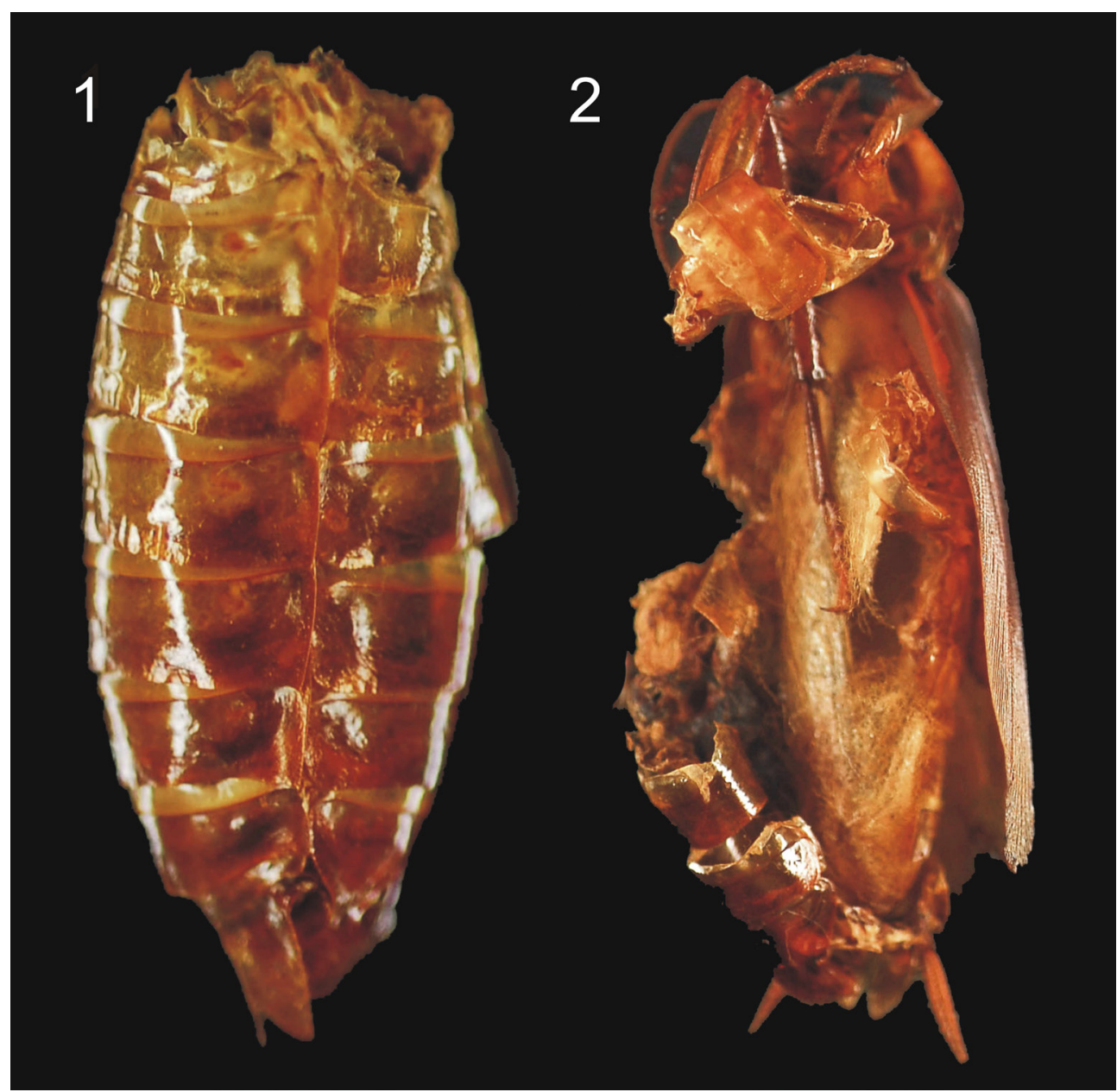

Figs 1-2: Abdomen and thorax of the host Periplaneta americana with cocoons of Ampulex compressa inside: 1 not dissected; 2 dissected. 
Menke, A. S. \& Yustiz, E. 1983: Ampulex compressa (F.) in Venezuela (Hymenoptera, Sphecidae). - Proceedings of the Entomological Society of Washington 85: 180.

Pulawski, W. J. 2015: Catalog of Sphecidae sensu lato (= Apoidea excluding Apidae) - Number of species. Available in: http:// research.calacademy.org / sites / research.calacademy.org / files / Departments / ent / sphecidae / Number_of_Species.pdf. Accessed on April, 2015.
Stuart, A. E. \& Hunter, F. F. 1998: End-products of behaviour versus behavioural characters: a phylogenetic investigation of pupal cocoon construction and form in some North American black flies (Diptera: Simuliidae). - Systematic Entomology 23 (4): 387-398.

Willimas, F.X. 1942: Ampulex compressa (FABR.), a cockroach-hunting wasp introduced from New Caledonia into Hawaii. - Proceedings of the Hawaiian Entomological Society 11: 221-233.
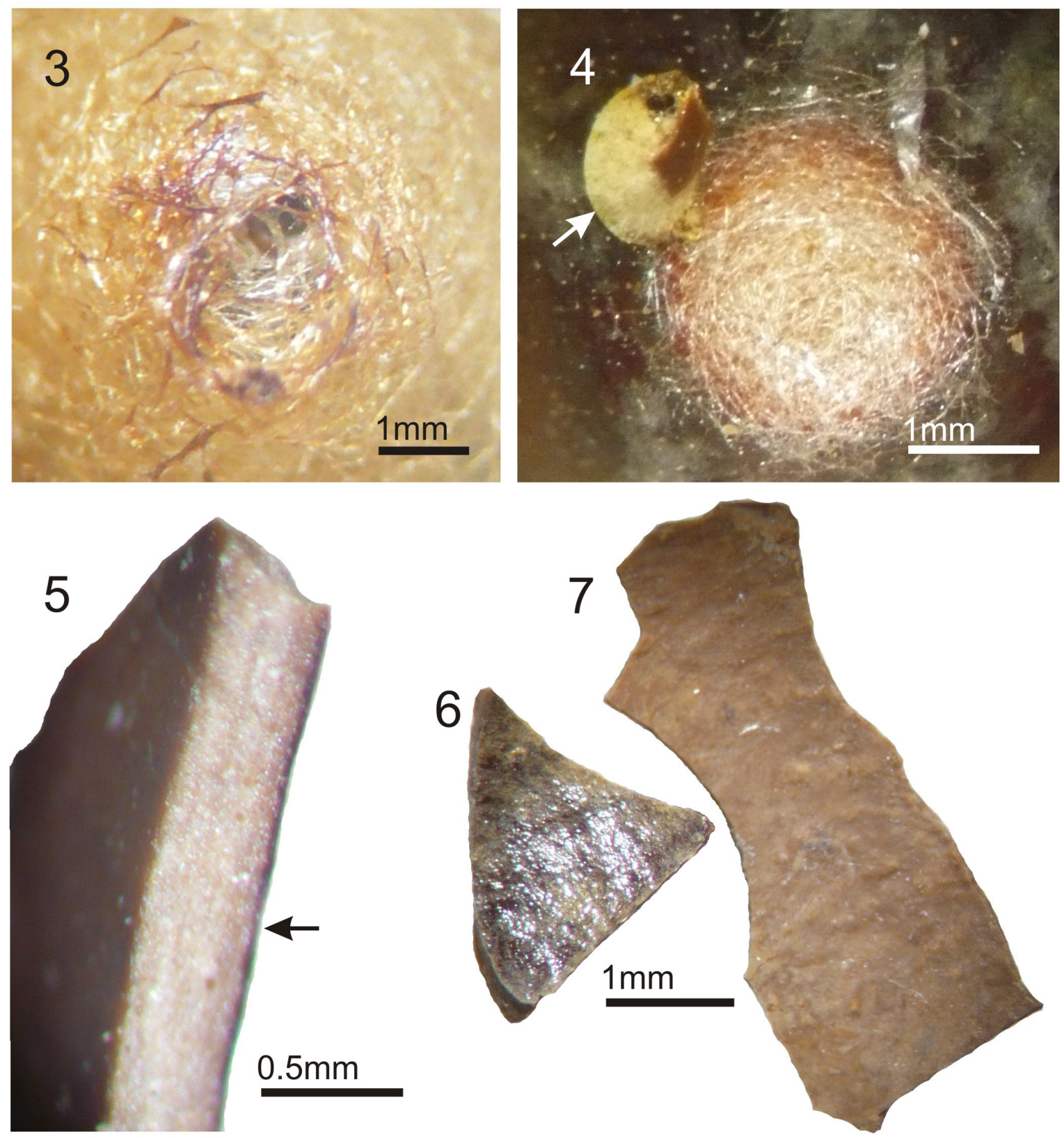

Figs 3-7: Ampulex compressa, cocoon: 3 apical portion of the external capsule, showing opening; 4 inner view of the apical extremity of the internal capsule, showing the silken plug that close the apical opening, seta pointing a grain of uric acid attached to the wall; 5 wall of the internal capsule, setae pointing the inner face; 6 inner face of the internal capsule with the brilliant coating pellicle; 7 inner face of the internal capsule without the brilliant coating pellicle. 